\title{
JESSICA WANG
}

\section{Imagining the Administrative State: Legal Pragmatism, Securities Regulation, and New Deal Liberalism}

After more than two decades of "bringing the state back in," law persists as a neglected stepchild in the history of American state-building. Legal historians have identified a profound transformation in jurisprudence that took place during the late nineteenth and early twentieth centuries, but they have said relatively little about how radically new conceptions of law influenced public policy during the 1930 s. ${ }^{1}$ Conversely, historians of public policy have written extensively about American political development, the nature of bureaucratic autonomy, and the uses of economic knowledge in upholding the administrative state, but the role of law and jurisprudence in recasting state power has remained elusive. ${ }^{2}$ Moreover, as William J. Novak has observed, both groups of scholars remain hamstrung by the inherited wisdom of Progressive historiography, and they continue to subscribe to a familiar litany of cases from Lochner to Schechter that undergirds a grand narrative about law's sole function as an impediment to state-building. As a corrective, Novak has urged historians to consider more carefully the "massive amount of everyday lawmaking" and "structural sociolegal changes" rendered invisible by the court battles of the first third of the twentieth century. Although largely unacknowledged in public discussion and debate, such developments ultimately provided critical support for the consolidation and legitimation of the modern American state. ${ }^{3}$

This essay examines the place of law in the making of the New Deal state by focusing on three of the early chairmen of the Securities and Exchange Commission (SEC)-James M. Landis, William O. Douglas, and Jerome N. Frank-and the key role jurisprudence played in their efforts to regulate the securities market and uphold the administrative state. General histories of the New Deal devote little attention to the SEC, but

THE JOURNAL OF POLICY HISTORY, Vol. 17, No. 3, 2005.

Copyright () 2005 The Pennsylvania State University, University Park, PA. 
in the 1930s the commission emerged as one of the Roosevelt administration's most robust, creative, and successful agencies, and its reputation for energetic and effective oversight of the nation's securities markets extended well into the postwar years. ${ }^{4}$ Its very vigor and success attracted powerful opposition, and as the intense political and legal struggle over administrative power and the threat of statism came to a head during the New Deal years, a considerable portion of the enmity toward the New Deal's expansion of administrative government targeted the SEC. In response, Landis, Douglas, and Frank invoked novel developments in jurisprudence, especially a redefinition of legal science that integrated knowledge production with state functions, in order to justify and defend the prerogatives of the New Deal state. All three had previously achieved academic renown as advocates of innovative approaches to law, and these new currents in jurisprudence, which I will refer to as "legal pragmatism," profoundly influenced their public defense of the administrative state during the 1930s and early 1940s. The history of securities regulation thus provides significant insight into previously unrecognized aspects of New Deal liberalism's intellectual underpinnings, as well as the general place of law in the history of American state-building.

My narrative begins in the realm of legal thought, where competing notions of law as science broached hard questions about the nature of knowledge, the realities of social life, and the purpose of law amid the upheaval of American industrialization during the late nineteenth and early twentieth century. From the broader "revolt against formalism" emerged two intellectual movements within academic law-first sociological jurisprudence, and subsequently legal realism-that together defined a new legal pragmatism. This profound rethinking of knowledge and scientific truth as contingent upon social realities sought answers to the problems of the modern political economy in the ongoing exploration and creation of social facts. ${ }^{5}$ Many of the New Deal lawyers, including the three SEC chairmen discussed here, came from universities permeated with the intellectual and political excitement of pragmatic jurisprudence, and they brought their enthusiasm for policy experimentation to federal agencies in the 1930s. Under the leadership of Landis, Douglas, and Frank, legal pragmatism exerted a powerful pull on the SEC's regulatory work, and it provided a philosophical basis for their state-building efforts. For them, the New Deal's dedication to expert-led policymaking, faith in administrative flexibility and discretion, and belief in the compatibility of administrative government and democratic oversight all rested upon the promise of the new jurisprudence. 


\section{Origins: Legal Pragmatism and a New Science of Law}

Recent scholarship has vastly complicated historians' understanding of nineteenth-century jurisprudence and the historical realities behind classical orthodoxy (also known as formalism, conceptualism, or classical legal thought). A once-simple schema that described a neatly delineated transition from formalism, which envisioned legal science as the identification of universal principles of legal truth through systems of taxonomic classification and geometric reasoning, to pragmatists' relativist and experiential concept of knowledge, now requires minute shading and nuance. Old verities about the rigid scientism of classical legal thought and its dominance over nineteenth-century law have given way to incisive discussions over such matters as whether the inductionism of Baconian science advocated by nineteenth-century legal treatises ever significantly manifested itself in judicial practices, the extent to which the introduction of the case method in legal education constituted a continuation of or major departure from the universalist conceptions of truth that defined nineteenth-century legal science, the question of formalism's emergence as a means of legitimating the new corporate political economy, and the actual degree of classical orthodoxy's hostility toward the administrative state. ${ }^{6}$ Nonetheless, there remains a general consensus that something changed profoundly during the last third of the nineteenth century. Whether the product of the Civil War, the needs of corporate capital, or the legal community's professionalizing mission, American jurisprudence increasingly reflected a commitment to individual rights over a generalized common good, and it appealed to "a science internal to the law" as a means of naturalizing legal principles. In a rapidly changing industrial society, the idea of law as an exercise in scientific reasoning helped to preserve an image of neutrality in judicial decisionmaking as courts defined new boundaries of moral and political economy. ${ }^{?}$

For Landis, Douglas, and Frank, the finer points of historiography mattered far less than what they perceived as the failure of law to adapt to the realities of modern industrial society. The three SEC chairmen belonged to a decades-old critical tradition that viewed classical orthodoxy as an impediment to social and economic justice and proposed an amalgamation of philosophical pragmatism and progressive reform as a muchneeded alternative. The most dramatic deconstructions of law emerged at Yale and Columbia during the late 1920s and early 1930s, where a self-proclaimed movement of legal realists built upon a longer-term intellectual rebellion against formalism, particularly the sociological jurisprudence of 
Roscoe Pound, in order to deliver bold and iconoclastic attacks on classical legal thought. ${ }^{8}$ Drawing inspiration from pragmatism, the adherents of both sociological jurisprudence and legal realism rejected textbook models of legal practice and insisted that law could not be comprehended, and ought not be idealized, as an exercise in syllogistic reasoning based on the application of timeless legal axioms. Instead, a scientific understanding of law had to depend on real-world observation, the primacy of actual legal practice over abstract theory, and a recognition of the roles that contingency, historical circumstance, and individual personality played in the judicial process. Unconstrained by notions of law as a systematic realm of blind, objective justice, legal pragmatists translated their theoretical apparatus into a case for the imaginative use of law and public policy to address the new social and economic problems of the industrial age.

As part of a second generation of legal pragmatists, Landis, Douglas, and Frank were heir to the creative synergy between pragmatism and progressivism that energized American intellectual and political life in the late nineteenth and early twentieth century. Three key figures-Oliver Wendell Holmes Jr., John Dewey, and Louis D. Brandeis-loomed particularly large in the pragmatist redefinition of law as science that persisted on into the New Deal years. Holmes's famous dictum in The Common Law (1881) that "the life of the law has not been logic; it has been experience" provided the rallying cry for half a century of assaults on theoretical abstraction that failed to confront social realities. ${ }^{9}$ Holmes was part of the Boston circle that included Charles Peirce and William James, and his legal thought reflected the new philosophy of pragmatism and its insistence on the validity of experience over a priori commitments. ${ }^{10}$ Holmes also understood judges as makers of policy decisions, and he argued that their choices involved a balance of social interests, rather than an oracular declaration of revealed legal truth based on precedent. To the scientific pretensions of classical legal thought he offered a different version of legal science, one grounded upon a scientific understanding of society. ${ }^{11}$ All of these elements of Holmes's thought-the social, experiential quality of law, the policy dimension of the judge's role, and the importance of social science-later found their way into the legal realist attack on formalism. ${ }^{12}$

In John Dewey, legal pragmatists found a potent combination of intellect and conscience that melded philosophical inquiry and social action. As a University of Chicago professor in the mid-1890s and early 1900s, Dewey became a regular at Hull House, and he vehemently criticized the everyday harshness of industrial life and its atomizing effects on a brutalized workforce. His pragmatic approach to philosophy, which placed experience and consequences at the center of social existence, 
bolstered his political convictions. To Dewey, the public good was determined not by abstract principles, such as natural rights or the sanctity of private property, but by the operational criterion of whether or not social acts and their consequences aided individuals' realization of their own autonomy and contributed to their sense of solidarity as members of a democratic community. ${ }^{13}$ Dewey's ideas thus provided a philosophical basis for reform, and the opponents of classical legal thought eagerly took up the mantle of pragmatism.

The progressive zeal for social science, particularly the social survey as a means of revealing society's ills and finding ways to overcome them, also played a critical role in the evolution of legal pragmatism. ${ }^{14}$ In the legal profession, Louis D. Brandeis's "Brandeis brief" in Muller v. Oregon (1908), which mobilized a broad array of sociological data with only a minimum of legal argument in order to successfully defend a state-level protective labor law for women, represented the practical uses of social science and pragmatic inquiry for purposes of reform. From a pragmatist perspective, the Brandeis brief heralded the potential of a new age, one in which the facts of social conditions, and not appeals to abstractions such as liberty of contract, would determine legal outcomes, and empirical scientific research would replace geometric system-building as the new basis for American jurisprudence.

Harvard law professor Roscoe Pound's call for a "sociological jurisprudence" neatly crystallized the Progressive Era critique of classical orthodoxy and provided a well-defined, clearly articulated, and influential jurisprudence that grafted science to pragmatism. Pound's legal thought reflected diverse influences, including a doctorate in botany from the University of Nebraska, where Midwest botanists had abandoned the static taxonomical tradition in favor of understanding living organisms in their dynamic interaction with the environment, and three years as a law professor in Chicago, where Pound enjoyed stimulating encounters with social workers at Hull House and pioneering social scientists at the University of Chicago. After his move to Harvard in 1910, these experiences helped Pound to formulate a sociological conception of jurisprudence based on Deweyan pragmatism, social science, and the need for a legal order that could meet the challenges of modern industrial society. ${ }^{15}$ Formalism, Pound argued, erred in its confusion of means with ends, which sacrificed living social realities to judicial abstraction. Labor law, for example, remained mired in obsolete assumptions about freely bargaining individuals that bore no relationship to the realities of an industrial political economy. ${ }^{16}$ In the place of formalist first principles, Pound called for a pragmatic approach that concentrated on results rather than legal 
structure. "The pragmatic criterion," he observed, "is sound. The true juristic theory, the true juristic method, is the one that brings forth good works." 17

Where pragmatism provided guiding principles, the social sciences provided the means to pursue a sociological jurisprudence. Legal scholarship, Pound wrote, needed to "take more account, and more intelligent account, of the social facts upon which law must proceed and to which it is to be applied" and focus on "study of the actual social effects of legal institutions and legal doctrines," rather than law as an abstract system of formal rules. ${ }^{18}$ By so doing, sociological jurisprudence attuned law more closely to social needs. The advocates of sociological jurisprudence, Pound summarized, "look more to the working of the law than to its abstract content," "regard law as a social institution which may be improved by intelligent human effort," "lay stress upon the social purposes which law subserves," and "urge that legal precepts are to be regarded more as guides to results which are socially just and less as inflexible molds." ${ }^{19}$ Law emerged not as an unyielding natural order, but a human creation whose social, political, and economic consequences could be adjusted and readjusted in accordance with changing social conditions. Thus sociological jurisprudence provided a legal foundation for Progressive reform.

During the 1920s and early 1930s, these ideas expanded throughout legal academe in a variety of directions. Empirical studies of law, including Pound and Felix Frankfurter's classic survey of the criminal justice system in Cleveland, proliferated, and they enjoyed generous foundation support. At Columbia, and later at Johns Hopkins University, Walter W. Cook, Herman Oliphant, and Hessel Yntema took the sociological approach a step further in an effort to unite science, pragmatism, and empiricism by calling for the scientific study of legal institutions based on the insights of modern biology and physics, which they argued had replaced stagnant formalism with a natural world of change and indeterminancy. At Yale, the reigning center of legal realism, a stunning array of intellectually lively and strong-willed scholars, including Douglas and Frank, began to explore the full possibilities of the new jurisprudence through interdisciplinary study, empirical research, and wide-ranging theoretical critiques. As a result of this intellectual ferment, by the early 1930s the elite institutions had reoriented the academic understanding of legal science toward pinpointing the living realities of law in its dynamic relationship with social, economic, and political conditions and reconceptualizing the legal realm in accordance with the conditions of the modern political economy. With the coming of the New Deal, an energetic group of legal pragmatists flocked to Washington, and 
progressive jurisprudence entered the arena of public policy on the national level. ${ }^{20}$ As Landis, Douglas, and Frank worked to regulate the securities market, legal pragmatism provided both practical tools for everyday regulatory practices, as well as ideological means for promoting the New Deal's administrative state.

\section{Landis, Douglas, and Frank: Three Legal Pragmatists at the SEC}

Although the stock market crash was more symptom than cause of the Great Depression, in the 1930s it symbolized the reckless, uncontrolled nature of industrial capitalism and the misery created by a chaotic, unrestrained, and perilous marketplace. Progressive reform had led to the passage of numerous "blue sky" laws (so-called because one legislator claimed that without laws to protect ordinary investors, cheats and swindlers would sell everything but the sky itself) by state governments in the 1910s and 1920s, but the securities market remained rife with fraud and corruption. During the boom years of the 1920s, the need for regulation did not appear urgent, but with the crash of 1929 and the financial upheaval that followed, pressure mounted for federal regulation. Herbert Hoover preferred voluntary action on the part of Wall Street and vacillated over the question of federal intervention, but when Roosevelt assumed the presidency, he immediately made securities legislation a top priority. In May 1933, Roosevelt signed the Securities Act of 1933, which ordered issuers of new securities to register with the Federal Trade Commission and fully disclose a wide variety of financial data. A year later, Congress passed the Securities and Exchange Act of 1934, which extended the earlier act's registration requirements to all securities traded on the nation's stock exchanges, provided additional regulation of the exchanges and their practices, and overcame the bureaucratic limits of the FTC by creating a new administrative agency, the Securities and Exchange Commission, to regulate the securities market. ${ }^{21}$

Roosevelt appointed longtime Wall Street speculator and Democratic party insider Joseph P. Kennedy the SEC's first chairman in order to appease the financial community, but Kennedy stayed with the commission for only a little more than a year. ${ }^{22}$ The next three chairmen-Landis, Douglas, and Frank-were all legal pragmatists whose jurisprudence profoundly influenced their understanding of New Deal public policy and the administrative state. Landis, a protégé of Felix Frankfurter, had established a reputation for academic brilliance before 
the age of thirty. As a faculty member at Harvard Law School, he pushed beyond the bounds of formalism by specializing in administrative law, labor law, and legislation, all relatively young fields that broached legal territory outside the traditional categories of classical orthodoxy. ${ }^{23} \mathrm{His}$ innovative course on legislation provided an expression of Landis's commitment to pragmatic jurisprudence as well as a ticket to the New Deal. In accordance with legal pragmatism's view of law as a dynamic process rather than a static set of rules, Landis's seminar moved beyond the written statutes to consider all stages and dimensions of the legislative process. ${ }^{24}$ State-level securities laws constituted the seminar's theme for the 1932-33 academic year, and Landis's newly developed expertise on the subject brought him to Washington, D.C., where he helped draft the Securities Act of 1933 and the Securities and Exchange Act of 1934. After the passage of the 1933 act, Landis joined the FTC as a commissioner. He subsequently became one of the five commissioners of the newly formed SEC, and after Kennedy's departure in September 1935 Landis ascended to the SEC chairmanship.

Legal pragmatism lay at the heart of Landis's approach to regulation. As he explained to a Harvard colleague in May 1936, the socially situated nature of law as a "public profession" supported its regulatory application. Writing from the chairman's office, he observed that "law is an instrument, or a social institution, if you will, for the advancement of the health of society as a whole." Too often, however, abstract discussions of the appropriateness of state versus federal action impeded the implementation of regulatory measures, "with the result that we are obtaining an ever increasing area in which there is no governmental regulation at all." The predominance of classical legal thought in the law school curriculum, he suggested, had created the impasse. ${ }^{25}$ The solution, in Landis's mind, lay in a flexible conception of law's uses, and the expansion of an expert-guided administrative state.

Progressive reformers had long embraced expert objectivity as a means of transcending politics and implementing rational management of an increasingly complex and bureaucratic society. ${ }^{26}$ Many New Dealers, including Landis, similarly extolled the virtues of expertise, but they were nothing if not political and knew better than to expect an escape from politics. Political demands, however, did not lessen Landis's dedication to expert knowledge, and he forged the SEC into an agency that integrated specialized knowledge into its regulatory practices at every level, built close ties with professional communities, particularly engineers and accountants, and delegated considerable authority to its expert constituencies. $^{27}$ 
Upholding professional prerogatives provided one means of promoting indirect oversight and external self-regulation, Landis's preferred regulatory approach. His partiality arose in part from political considerations, but it also reflected legal pragmatism's view of law as a process and ongoing experiment, rather than a set body of rules. As Landis noted in April 1936, the commission might have adopted a tight set of regulatory mandates, such as "limiting the cost of distribution, insistence upon appropriate amortization provisions, requirements for adequate and indestructible voting power, independent and supervised valuation of property for which stock is issued, or control over the contents of trust indentures, to mention only a few of the possibilities." Instead, it relied upon "the duty to secure a measure of disclosure in the hope that an informed public would have both the ability and independence to guide the direction of its national savings." Landis's conclusion pointed to the old progressive faith that knowledge was power, and awareness of facts could solve social and economic problems: "The hope is, that in the light of knowledge, investment can most profitably be still a matter of private choice." ${ }^{28}$ Although regulation required restrictions on particular undesirable practices, it also had to preserve the spontaneity of social life by providing individuals with the means to make choices free from the coercion of both rapacious corporations and a potentially heavy-handed federal government. The establishment of a happy medium between those two poles of coercion lay in the scientific study of regulatory problems and the application of expert knowledge through policy experimentation.

In order to implement this vision of research and policy formation within the commission, Landis brought in William O. Douglas to pursue the social science agenda of legal pragmatism within the SEC. As Mary O. Furner and Barry Supple have observed, the "quest for economic knowledge" has comprised "one of the important building blocks of the modern state." ${ }^{29}$ From the very beginning, the SEC constituted a site for the production and application of economic knowledge, and its research enterprises allowed the agency to extend its functions to the active formulation of policy. As director of the SEC's Protective Committee Study, Douglas brought legal realism's reformist brand of empirical social science to bear upon regulatory problems, and even as his research underscored the limitations of early twentieth-century social science, it also demonstrated its political power as a means of generating authoritative testimony to support new policy directions.

The progressive enthusiasm for social surveys in the earlier part of the twentieth century had concentrated primarily on local communities and the conditions of life for immigrants and the working class, but 
during the 1920s scholars began to extend those methods to the empirical investigation of large-scale economic phenomena. ${ }^{30}$ Douglas joined the faculty of Yale Law School, the hotbed of the legal realist movement, in 1928, where he launched pioneering studies of bankruptcy as part of legal pragmatism's effort to replace theoretical abstraction with social realities. ${ }^{31}$ Almost no data existed about the basic facts of bankruptcy, and the long-standing federal bankruptcy law rested upon untested assumptions rather than concrete evidence. In that context, Douglas's research attempted to create economic knowledge that would provide law a firmer foundation. Although not without methodological shortcomings (indeed, the scientific agenda of legal realism would ultimately falter when its most ardent advocates found the general conclusions they anticipated too difficult to formulate convincingly amid a clutter of empirical facts), Douglas's work by the early 1930s began to demonstrate some of the promise of empirical social science as a means for uncovering the living realities of law. 32 One of his articles, "Some Functional Aspects of Bankruptcy," for example, employed questionnaires to examine 1,500 cases and provide vital statistics about bankruptcy among businesses and wage earners in Newark and Boston. As Douglas noted, few such statistics existed, and as a result, previous reform efforts had been directed toward the administrative machinery of bankruptcy "without seriously considering the totally different ... engineering problem of the social need, use, and function of the particular machinery or its parts." The realities of bankruptcy suggested the variety of circumstances that courts had to consider in their disposition of cases, particularly the need for adequate accounting as a condition for releasing businesses from their debts. ${ }^{33} \mathrm{~A}$ second article used court records from 1,004 New Jersey cases to question some of the basic premises of bankruptcy law, which assumed that creditors, because of their interest in recouping their assets, would want to play a central role by electing trustees, examining bankrupts, and participating in other areas of bankruptcy proceedings. In reality, so few assets remained in most cases that it was not worth the time of creditors, many of them absentee, to take an active interest, and in the large majority of cases they did not even participate in the selection of a trustee. Meanwhile, bankruptcy courts themselves, contrary to the theory of how bankruptcy proceedings were supposed to work, generally handled cases with only the most cursory examination. In response, Douglas and his co-author, J. Howard Marshall, called for more rigorous bankruptcy hearings. "Only by some such method," they wrote, "can any intelligent undertaking for more effective social control over failures be initiated." 34 
Douglas's empirical research and analytical writings, combined with a flair for self-promotion, established him as an intellectual powerhouse and rising young star among the legal pragmatists. Landis particularly admired an article on railroad reorganizations, in which Douglas highlighted the tendency of protective committees to perpetuate old management instead of shareholders' interests, and when the Securities and Exchange Commission began to fill its main staff positions, Landis approached Douglas to head the commission's research on protective committees. ${ }^{35}$ The job was an important one: Section 211 of the Securities and Exchange Act of 1934, in anticipation of revisions in bankruptcy reorganization laws, provided for research on the protective and reorganization committees that were supposed to represent investors' interests following declarations of bankruptcy. Douglas readily agreed to take the job, and he began commuting between New Haven and Washington in the fall of 1934; in 1936, he became an SEC commissioner, and he rose to the chairmanship in the fall of 1937.

As head of the Protective Committee Study, Douglas applied the methods of his bankruptcy research and employed a combination of questionnaires, interviews, review of documentary evidence, and detailed case studies based on lengthy SEC hearings as the PCS undertook a massive, eight-part study of protective committees. Originally, the study was supposed to be completed by January 1936, but the subject proved so daunting and complex that the last volume was not published until 1940. The unwieldy nature of the PCS revealed legal realism's uncertain footing in empirical social science. Although originally conceived in terms of scientific investigation, the study ended up as a hybrid-part social science research project and part traditional government investigation-and the different parts of the study varied widely in presentation and method. Its haphazard quality indicated the limits of legal realism's vision of social science as well as the complex meanings of empirical knowledge in policymaking. ${ }^{36}$ Nonetheless, the study demonstrated the efficacy of empirical knowledge to the formulation of regulatory policy, even though it did not lead to the passage of a comprehensive reform package, as originally intended. The timetables of research and congressional politics failed to mesh, and the SEC's slowness in completing the study, combined with tactical political mistakes by Douglas, doomed its grander aspirations. Nonetheless, the PCS could boast significant accomplishments with the passage of the 1938 Chandler Act, which overhauled corporate bankruptcy reorganizations, and the 1939 Trust Indenture Act, which strengthened protection of bondholders' rights in the restructuring of corporate debt. The establishment of Chapter X bankruptcy under the 
Chandler Act was particularly important as a mechanism for providing the federal courts with access to the SEC's specialized expertise as they dealt with complex corporate reorganizations, and for establishing independent trustees to protect shareholders' interests. Chapter X governed bankruptcy reorganization for the next forty years. ${ }^{37}$

Jerome Frank, the last of the SEC's legal pragmatist chairmen, came to the New Deal with a reputation as both a brilliant corporate lawyer and iconoclastic legal thinker. His 1930 tour de force, Law and the Modern Mind, caused a sensation in legal circles for its bold and irreverent attack on classical orthodoxy and its deconstruction of the judicial process. Frank's invocation of Freudian psychology and the desire for a father figure as the source of formalism's futile longing for certainty prompted the greatest outrage, but more significant was his pragmatic concept of knowledge, which insisted on the need to replace a concept of science as a search for static truths with what he called "the scientific spirit," a commitment to ceaseless inquiry and experimentation as the fundamental basis of science. As he argued throughout Law and the Modern Mind, law needed to free itself from its dogmatic adherence to universalist conceptions by adopting "the spirit of the creative scientist, which yearns not for safety but risk, not for certainty but adventure, which thrives on experimentation, invention and novelty and not on nostalgia for the absolute, which devotes itself to new ways of manipulating protean particulars and not to the quest of undeviating universals." Lawyers and jurists, Frank contended, needed to develop a similarly daring frame of mind and cast away the static view of law as a set of unchanging and unyielding principles in favor of understanding law as an experimental, dynamic process. "The practice of law," he declared, "is a series of experiments, of adventures in the adjusting of human relations and the compromising of human conflicts." 38

Law and the Modern Mind established Frank as one of the leading lights of legal realism, and he soon became a regular visitor at Yale Law School, in addition to continuing his regular work on corporate reorganizations at a high-power New York law firm, where he concentrated on defending the rights of small security holders. Drawn toward the political excitement of the New Deal, he became general counsel for the Agricultural Adjustment Administration in 1933, where he battled to defend consumers' interests and protect tenant farmers; his latter efforts led to his ouster in the 1935 purge of the AAA. ${ }^{39}$ Frank still had many friends and allies in Washington, however, and dismissal did not mean political exile-he merely moved laterally to legal duties at the Reconstruction Finance Corporation and the Public Works 
Administration. He returned to private legal practice out of financial considerations in 1936, but a year later, upon Douglas's recommendation, Roosevelt lured him back to public service with an appointment as an SEC commissioner. After Douglas's elevation to the Supreme Court in 1939, Frank became SEC chairman.

Frank, like Landis and Douglas, expressed his legal pragmatism as a New Dealer through his view of law as a flexible instrument for serving social needs. Early in his tenure as general counsel at the AAA, he forthrightly declared his commitment to "experimental jurisprudence" and "experimental economics" as the essence of the New Deal, and in Deweyan fashion, he described "legal institutions and devices" as "human contrivances to be judged by their everyday human consequences." 40 At both the AAA and the SEC, Frank argued against universalized regulatory schemes and in favor of local, creative solutions to particular policy problems. ${ }^{41}$ For example, when Wall Street stalled on Douglas's earlier brokerage bank idea, proposed in response to the reality of brokers' de facto banking functions, Frank exerted pressure for appropriate reforms. Forswearing any set commitment to brokerage banks as the ultimate solution, he challenged the New York Stock Exchange to propose alternative measures that would protect investors' funds from broker insolvency. ${ }^{42}$ Throughout his years at the SEC, Frank consistently embraced administrative flexibility over rigid rules. As he chided one legal correspondent, who objected to the SEC's investigatory powers on the grounds of statutory vagueness, "the complexity of the fact situation" in matters related to securities "makes it impossible to reduce securities legislation to yardstick principles." He continued, in language typical of his legal realism, "You know that 'law' cannot be reduced to mechanical standards and written into statute books." ${ }^{43}$ Frank also shared his legal pragmatist colleagues' strong belief in the aggressive use of administrative power to serve policymaking purposes. As the political battle over agency government shifted from the Supreme Court to the legislative realm, Landis, Douglas, and Frank devoted increasing energy to articulating a legal pragmatist rationale for the administrative state.

\section{Legal Pragmatism and the Defense of the Administrative State}

Administrative government had expanded rapidly in the late nineteenthand early twentieth-century through the progressive commitment to expert-led commissions and agencies as the key institutions for the execution of public policy in a complex, modern society, but 
administrative agencies at the federal level encountered questions of legal legitimacy from the very beginning. The Supreme Court's evisceration of the Interstate Commerce Commission's power to regulate railroad rates, primarily on the grounds of unconstitutional delegation of authority, signaled the problems that lay ahead. The creation of administrative agencies with the ability to generate new rules could not be reconciled easily with a constitutional system that placed sole legislative authority in the Congress. Investing unelected officials with the freedom to formulate policy also risked a lack of public accountability that ran counter to democratic political theory. To legal pragmatists, however, administrative authority offered necessary means for tempering the harshest aspects of industrial society and bringing order to the modern political economy through expert management. From their perspective, the main task lay in creating a legal and political culture that would reject abstract and obsolete formulas and embrace new forms of political authority tailored to the needs of modern times.

Within boundaries set by the Supreme Court, administrative government grew in fits and starts during the early decades of the twentieth century, and by 1920 the American state had arguably experienced a transition from a "state of courts and parties" to an administrative state characterized by expanded presidential power and increased authority in executive branch agencies. ${ }^{44}$ Nonetheless, the status of administrative government at the national level remained shaky, and the New Deal faced stringent legal tests as its agencies sought to implement regulatory and relief programs. Indeed, the Supreme Court's invalidation of Title I of the National Industrial Recovery Act in 1935 sent a chill through the Securities and Exchange Commission, and SEC staffers worried that their agency would be next on the constitutional chopping block. The Securities and Exchange Commission survived its main constitutional test in Jones v. SEC (1936), in which the high court voided a particular procedure in the commission's handling of stop-order proceedings but declined to consider larger constitutional questions. In his majority opinion, Justice George Sutherland nonetheless delivered a stern warning against the potential for administrative authority to descend into "autocracy" and "arbitrary power." The judicial system, he indicated, would remain on guard: "Against the threat of such a contingency the courts have always been vigilant." 45

Challenges to the New Deal's administrative state arose from other quarters as well. In 1934, the American Bar Association (ABA) launched an initiative to restrain the judicial power of administrative agencies, and it periodically offered legislative proposals over the next several years. 
Roscoe Pound, who had viewed sociological jurisprudence as a basis for court reform and not the expansion of new forms of political authority, had grown increasingly dismayed over legal realist critiques of judicial authority, and he played a major role in the bar's efforts. By the late 1930s, the changing political climate appeared to favor the ABA's agenda. Following Roosevelt's politically disastrous court-packing plan and its fallout in the 1938 mid-term elections, the new Congress sought to contain the New Deal's expansion of federal power through the WalterLogan Bill, which sought stringent judicial review measures as a way to rein in what Pound and the ABA had condemned as "administrative absolutism" in the 1938 report of the Special Committee on Administrative Law. ${ }^{46}$ In the congressional debate over administrative procedure, the SEC and the National Labor Relations Board emerged as the most prominent targets. Roosevelt vetoed the Walter-Logan Bill in 1940, after a long and bitter struggle between proponents who saw administrative agencies as harbingers of Soviet totalitarianism and defenders of administrative government who believed that advocates of the bill wanted the New Deal's destruction. ${ }^{47}$ The Walter-Logan Bill arouses little passion today, but at the time it generated a pivotal conflict, in which the New Deal agencies faced a potentially deadly threat to their regulatory authority. As Chester Lane, the SEC's general counsel, saw it, the bill sought "to hamstring and defeat the operations of administrative agencies, and where it is not possible totally to defeat administrative activity, to surround that activity with such extensive ready-made opportunities for delay and litigation by special interests that the activity will lose all its effectiveness." 48 In this context, the legal reformers of the SEC faced powerful political pressures to justify their right to regulate, and to demonstrate both the virtues and necessity of administrative government by experts.

Landis, Douglas, and Frank responded by mobilizing legal pragmatism in support of the administrative state. Taken together, their analyses built the case for expertise and administrative discretion as means for the flexibility necessary to manage the corporate political economy. Administrative government, they argued, did not threaten democratic rule, but, rather, provided the best way to represent and promote the public interest given the complexities of economic relationships in modern society.

Landis incorporated all these themes in the theory of the administrative state that he constructed during the 1930s. He wrote his bestknown work, The Administrative Process, after he left the SEC to become dean of Harvard Law School, but his construction of a public philosophy 
to legitimate the administrative state began earlier, with the speeches and public writings of his SEC years. Through his experiences as a regulator, he developed and articulated a rationale for administrative government based on his faith in expertise and his beliefs about the nature of modern life, and he vigorously defended the state structures created by the New Deal.

Most of the New Dealers, like the progressives a generation earlier, believed that industrial society had produced a radical disjuncture between past and present, and that modernity required novel forms of statecraft. ${ }^{49}$ Landis was no different, and his philosophy of government identified the rise of administrative power as the natural and necessary product of a modern and scientific age. As early as 1934, he suggested that "the demand for administrative tribunals arises because of the breakdown of the legal system in particular fields," in which the problems of modern society "are too complex, too difficult to be handled by the average judge." Under contemporary conditions, expert-manned agencies could address matters of public importance more effectively than the judicial system. In the field of labor relations, for example, Landis argued that the decisions of the National Labor Board and its successor, the National Labor Relations Board, held "more wisdom" than "fifty years of judicial handling" of industrial labor relations. The boards, he contended, embodied "a more scientific approach," one that could "grapple concretely" with the realities of industrial life in a way that the courts had failed to do. Landis also pointed to securities regulation and the history of regulatory legislation more generally as another demonstration of the virtues of legal pragmatism over rigid adherence to the common law. "This legislation," he declared, in a textbook invocation of legal pragmatism, "reveals the effort to deal with concrete, living problems, to reach solutions that are dictated by political and social expediency, as distinguished from what are considerations often of no present moment that govern too many court decisions." 50

Beginning in early 1937, Landis gradually elaborated upon these ideas. In a speech before the Swarthmore Club in February, he outlined the historical development of the administrative commission from the Interstate Commerce Commission onward. According to Landis, the administrative agency evolved organically-it "came into being not as a single comprehensive philosophical conception but by a process of empirical growth." Critics decried the haphazard nature of administrative government, and the proliferation of localized, specific rules at the sacrifice of generalized governing principles, but legal pragmatists such as Landis made a virtue of this supposed deficit. "Administrative agencies," he 
observed, "are the products, not of dogma or of abstract theory, but of the gradual development of control by a democratic government over the varying phases of our economic life.... it is banking, insurance, utilities or railroads that form the dominating motif, rather than some highly theoretical doctrine as to powers that should or should not be possessed." 51 Political entities such as the SEC, Landis indicated, resulted from a process of knowledgeable adjustment to novel circumstances, not the implementation of grand, overarching theories. This pragmatic understanding naturalized administrative government, thereby replacing the specter of intrusive state power with institutional adaptations that appeared minimal, gradual, and absolutely necessary.

Landis expanded upon this idea a few weeks later when he spoke before an audience of law students in Washington, D.C. There he described a series of new economic rights that had emerged from industrial society, and he characterized change and novelty as intrinsic to social life. "The history of our law," he commented, "is replete with illustrations of the creation of new rights." Through a difficult process of social conflict, labor's right to collective bargaining continued to evolve in new directions; other economic prerogatives still in the making included the living wage, consumer rights, and investor protection. Social change also led to demands for "new machinery" when traditional legal structures, namely, "the established mechanisms of the common law," failed to preserve existing rights. Landis explained, "The normal processes of litigation prove themselves, for different reasons, to be ineffective in bringing about the practical recognition of recognized rights. They fail either because of the cost that attends the process, because of the delay that it involves, or because of the inability of men not expert in highly specialized fields to apply accepted principles to new situations." By embracing new institutional forms, legal pragmatism offered a solution to the deficiencies of the common law. "The instinct for a living law," Landis declared, "refused to accept frustration. It simply seeks other forms for its realization." Administrative government thus materialized as a way to compensate for the inadequacies of the judicial process and provide means for the "social control" of industrial society and its problems. ${ }^{52}$

In July, as his chairmanship of the SEC neared its end, Landis expounded further on the nature of the modern economic transformation that had spawned administrative agencies, with added reassurances as to their democratic character. Speaking before the Indiana State Bar Association, Landis again outlined the historic development of federal regulatory bodies and the new economic rights that they protected, including "the security of our bank deposits, the safety of our life 
insurance, our protection against fraud and chicanery in the sale of securities, our necessity for having light and power at reasonable rates, our protection against discrimination in railroad tariffs, or as workmen, our protection against unfair discrimination in employment or our right to compensation for industrial accident." All these rights, he argued, "spring out of the necessities of modern civilization.... These rights are the liberties peculiar to modern civilization, and the agencies of their protection are administrative rather than judicial." In other words, modern life and the need for specialized knowledge in myriad areas of private life and its regulation necessitated a transition from judicial to administrative sanction and oversight. ${ }^{53}$

To those who argued that administrative agencies symbolized autocratic state authority, Landis responded that, to the contrary, they enhanced democratic rule in a society where economic life could no longer be understood in terms of interactions between lone individuals. Instead, "the increasing social interdependence of modern life has made regulatory activity an increasing feature of government." ${ }^{44}$ Landis, like most of the New Dealers, admired Adolf Berle and Gardiner Means's The Modern Corporation and Private Property (1932), which had detailed the twentieth-century separation between ownership and management in large business enterprises, a new economic reality that in effect rendered corporations quasi-public entities rather than agglomerations of private wealth. In this changed economic context, individual workers were not the only persons left powerless in their negotiations with capital. Ordinary investors who in theory possessed ownership rights lacked all meaningful control over corporate enterprise. As an example, Landis cited the situation of a shareholder faced with a corporate reorganization: "The small investor who sincerely wishes to oppose a plan of reorganization sponsored by the management is practically helpless. Even if he can succeed in organizing a small minority committee, the cost of making the type of investigation necessary to convince a judge of the inequity of the proposed plan is such as to be beyond his means." The SEC, however, could examine a reorganization plan "independently from the bottom up" and act on the small investor's behalf where necessary. In so doing, the commission defended not simply the individual, but the public at large. "The agency explores [the small investor's] claims," Landis stated, "not because it is his but because of its interest in the great class of individuals of whom he is one." In essence, administrative government brought public authority to bear where the inequities of economic power left individuals without practical legal recourse. Agencies such as the SEC provided "legal aid and assistance to groups of individuals powerless 
themselves to act and incapable of being welded together into a unit substantial enough to bear the burden of litigation." ${ }^{55}$ Hence, far from constituting a threat to individualism, administrative government protected the individual from the privations of the modern political economy.

Landis returned to Harvard in the fall of 1937, but he remained deeply dedicated to the New Deal's success, and he continued to defend the prerogatives of administrative government. In January 1938 he went to Yale to deliver the prestigious Storrs Lectures, published later that year as his magnum opus in miniature, The Administrative Process. These and other writings recapitulated and elaborated upon the analysis he had developed during his last year at the SEC. The Administrative Process, for example, again emphasized the interdependent character of industrial society and the new economic and social problems "that flowed from the era of mechanical invention." ${ }^{56}$ Landis refined his earlier arguments with a fuller discussion of constitutional theory, however, and he addressed the question of delegation of power and administrative discretion head on. To those who believed in establishing a strict definition of appropriate administrative discretion, Landis's legal pragmatism argued against the possibility of generalization. The proper amount of discretion could not be established in the abstract-rather, it depended upon specific policy contexts. ${ }^{57}$ To those, such as the ABA, who wanted to rein in administrative discretion altogether, Landis responded that regulation could not proceed through strict, tightly defined rules spelled out in statute. Corporate control through stock ownership, for example, "could not be made to depend upon a mathematical ratio. A 5 per cent ownership of voting stock might in fact be equally as controlling as 51 per cent." ${ }^{58}$ Legal pragmatism dictated that the question of control could be determined only by a close examination of an existing situation, and not by resort to abstract formulas.

Landis also pointed to the many restraints that kept administrative power in check. Here his citation of experts' professionalism, fact-based assessments, and independence from political influence reflected progressives' long-held faith in scientific objectivity, but Landis added statutory limits on administrative discretion and the prospect of judicial review as institutional mechanisms for ensuring that administrative expertise remained properly accountable to political authority. ${ }^{59}$ The Administrative Process thus provided a brief for administrative government that rooted new forms of political power in the complex needs of the machine age, but located the containment of agencies' prerogatives not only in the scientific neutrality of experts but also in the continued viability of existing forms of oversight under the tripartite system of 
government. Fierce accusations that equated administrative discretion with fascism wilted into rhetorical excess and political posturing once one acknowledged the institutional restraints that continued to govern the SEC and other New Deal agencies.

Landis was hardly alone in his attempt to provide an intellectual rationale for the legitimacy of administrative government. His melding of modernity, expertise, and practical experience as the basis for open-ended inquiry in policymaking joined a broader effort among the New Deal's defenders to bring legal pragmatism to bear on behalf of the New Deal state. During his term as an SEC commissioner, and then Landis's successor as chairman, William O. Douglas also worked to build a philosophy of government that could justify the expansion of administrative power.

Douglas held views about administrative government very similar to Landis's. He highlighted the unprecedented nature of the modern political economy and the "organized, delicately interdependent society" it had created, and he also shared Landis's understanding of administrative agencies as a necessary response to technological change and the conditions of industrial society. ${ }^{60}$ It was pointless, Douglas argued, to resist the growth of administrative power. As he told a Washington, D.C., audience in 1938, "To manifest blind resentment against 'government by commission' or to engage in vain longings for the bucolic days before its advent is merely an exercise in futility. We can no more retreat from administrative government than we can turn back the clock upon our industrialization or the myriad processes of our urbanized society." Just as Landis had depicted administrative power as natural and inevitable, Douglas portrayed administrative agencies as a gradual, yet inexorable, consequence of social development. "Administrative authority," he observed, "is scarcely an innovation in our social order; on the contrary, it is a part of the empirical growth of the law, a response to the need for control by government over the expanding activities of business into new and uncharted fields." Thus Douglas underscored administrative agencies' novelty as responses to industrial society while at the same time denying critics' charges that they constituted radical forms of change. Douglas, like Landis, also stressed the democratic restraints-legislative oversight, judicial review, and the expression of public will-that kept administrative power from deteriorating into arbitrariness and autocracy. ${ }^{61}$

The reference to "the empirical growth of the law" indicated the influence of realist jurisprudence and its dynamic view of law upon Douglas's thought. Legal pragmatism also manifested itself elsewhere in Douglas's understanding of the administrative state. In his April 1937 
address in Washington, he called directly for "a pragmatic approach to government." The realities of industrial life, he declared, meant that "no abstract conception of administrative powers will suffice; that the form and nature of these powers are and will be indigenous; that their utilitarian rather than their theoretical characteristics are and will be dominant. No formalism can stand in the way of that advance." ${ }^{62}$ On repeated occasions, Douglas emphasized that the complexities of the modern political economy required not regulation by rigid, preset rules, but administrative discretion and flexibility. As he told a New York audience in the fall of 1938, discretion granted to the SEC by Congress provided "elasticity and flexibility," which allowed for rapid adjustment to shifting circumstances on a case-by-case basis. He continued:

The virtue of the administrative process is its ability to deal with technical, debatable, undefinable, or imponderable matters in a discretionary manner. It provides a realistic and sound alternative to hard and inflexible rules which proceed on the false assumption that right or wrong, black or white, constitute the only choice. But beyond that it permits of action not only case by case but by rules. A rule can be expanded, contracted or replaced in light of changed conditions or new experience. A formula fixed by legislative act tends to become more difficult to dislodge. Furthermore, the power to make rules means the power to deal with emergency situations-directly and with dispatch; in terms of minutes or hours rather than months or years. In a dynamic, fast-moving economic system responsible government must have a reserve of such powers if it is to save capitalism from its own complexities. ${ }^{63}$

Here Douglas's legal pragmatism sounded much like Landis's, but with a significant difference in tone. As an SEC commissioner and chairman, Landis focused on establishing the commission's legitimacy, and he avoided building too interventionist an image of the new agency. Given the SEC's politically delicate position in its early years, Landis wanted to reassure Wall Street that regulation did not mean the subordination of financial life to an intrusive federal government. Both men believed in an activist state, and in reality they shared much the same regulatory philosophy. But Landis was a more cautious person than Douglas, and in his public pronouncements, he concentrated on explaining the circumstances that necessitated administrative government and justified its basic existence. Douglas, by contrast, emphasized the vigorous use of the commission's authority not only to enforce existing regulations, but to 
establish new ones. By early 1937, he already knew of Landis's likely return to Harvard, and while he maneuvered for the SEC chairmanship and waited impatiently for his boss's resignation, he began to deliver forceful attacks on Wall Street's abuses. To the dismay of financiers, he insistently championed new regulatory efforts, and, as chairman of the commission, he earned a reputation as a forceful and successful regulator who extended the SEC's powers and aggressively targeted financial malfeasance. ${ }^{64}$

As part of this assertive regulatory stance, Douglas invoked legal pragmatism to defend the forthright application of the SEC's discretionary powers and uphold the commission's policymaking functions. As he observed in April 1937, administrative agencies' expertise provided means of constructing "new and constantly changing administrative devices," while their institutional dexterity allowed them to "operate interstitially where the heavier and more laborious court processes cannot reach." It was not enough, he argued, to take statutes at face value and apply "a narrow legalistic conception" to the commission's work. The SEC, of course, did not seek to violate congressional intent, but it also did not hesitate to use its authority to enforce "not only the letter but the spirit of the particular statute." In addition, "constant research and study on the periphery of present grants of power" allowed the SEC to respond "quickly and intelligently" to the ever-changing realities of high finance. Although the securities trade might prefer "assurance that the Commission's task ends with the strict legal powers which the Commission has," Douglas declared that "responsive and responsible administration can and will give no such assurance." The commission's mission, he insisted, required constant reevaluation and retooling of the SEC's own regulatory machinery. "An inventive liberalism," Douglas proclaimed, "is the only safeguard against repression or smug complacency." ${ }^{65}$ Pragmatic jurisprudence, he contended, provided the basis for an activist state that could react efficaciously to an economic environment in constant flux and protect the public interest.

Jerome Frank highlighted similar themes of expertise and flexibility as he tackled the ABA's Committee on Administrative Law head on during the late 1930s. Frank had long taken aim at inconsistencies within Pound's jurisprudence, especially Pound's continued belief in the possibility of legal rules within certain boundaries and his tendency to enshrine judicial authority, despite the extent to which his own sociological jurisprudence undercut both positions. ${ }^{66}$ As Pound and the ABA brought increased political pressure on administrative agencies, Frank responded publicly and directly from a legal pragmatist perspective. To those who argued for a crackdown on administrative discretion, Frank 
responded that by demanding agencies to apply concretely defined rules rather than exercise their own judgments about carrying out congressional mandates, they would bring on the very forms of stifling regulation that they feared. As he told an audience of Georgetown Law School alumni, administrative agencies were well aware that "regulation by government, if it is to be successful, must NOT be poured upon business." Instead, regulation required a process of flexible experimentation and adaptation. The SEC, he contended, operated in just this way-it "not only studied carefully before making its rules, but has changed its rules to fit conditions, modifying those rules which encountered unforeseen conditions or which caused unforeseen, unintended and undesirable consequences." The ABA's Committee on Administrative Law, by contrast, rendered law "a precise and virtually inflexible system of mandates and prohibitions" that offered only "unimaginative government

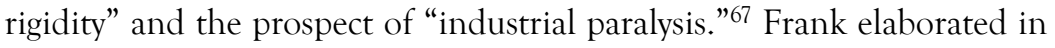
an address before the Association of the Bar of the City of New York six months later, when he played off Holmes and suggested that "the life of administration is not logic, it is experience." Where logic led to "awkward, unrealistic, impractical, strait-jacketting results," experience produced knowledge about the living realities of economic life. Administrative agencies, in particular, possessed the ability "to obtain that kind of detailed, day to day experience" and "secure the benefit of special knowledge acquired through continuous operation in a difficult and complicated field." ${ }^{68}$ The following year, he reemphasized to the same audience that in the context of modern industrial society, "inflexibility can only cause economic and political break-down." ${ }^{69}$ Effective regulation, he argued, required a dynamic bureaucracy free to make policy based on its continual assessment of market relations and economic conditions.

For Frank, Chapter X bankruptcy epitomized the value of a pragmatic approach to public policy. Back in 1933, he had published a detailed realist critique of courts' handling of corporate reorganizations that, in documenting the gap between theory and practice in existing bankruptcy proceedings and highlighting the need for close scrutiny of reorganization plans, presaged the kinds of reforms brought about by the Chandler Act. ${ }^{70}$ In an article on Chapter X proceedings, published just after he left the SEC to take a seat on the federal bench, Frank detailed more fully his understanding of administrative expertise and its role in corporate reorganizations. In earlier statements, Frank had criticized Pound for engaging in dogmatic attacks based on theoretical abstraction rather than "the actual work of the SEC." N1 Now, in response to Pound's 
characterization of the Chandler Act as a prime example of "administrative absolutism," Frank provided a lavish account of how the SEC's expert investigations facilitated corporate reorganizations under Chapter $\mathrm{X}$. Reorganizations, he argued, while litigative in form, were fundamentally administrative in character and largely involved nonlegal questions of finance and management. "Reorganization," he contended, "is something more than a brawl . . . it is an administrative problem in the solution of which the public, as well as the litigants, has an interest." Although judicial review was originally assumed to be up to the task of overseeing reorganization plans, a close look at the actual practices of lower courts demonstrated that all too often, expediency took precedence over "thoroughgoing examination of the enterprise and reasonably accurate determination of its prospects and value." By contrast, under Chapter X, the SEC provided sorely needed expertise that created a closer alignment between the theory of how reorganization proceedings were supposed to work and real-life experience. ${ }^{72}$

On this point, Frank underscored the complexity of the extensive investigatory efforts that the commission undertook on behalf of the courts and emphasized the advantages of administrative inquiry over litigation in corporate reorganizations. "After the Commission enters its appearance in a case," he observed, "it makes an intensive study of the debtor, its background, its financial structure, prospects, earning power and management, and the situation of the industry as a whole." The SEC's scrutiny operated at many levels and involved multiple experts: "Field examinations of the books and of the properties may be made by the legal, financial and accounting staffs. Elaborate investigations will be made of the state of the industry. Developments and trends will be analyzed on the basis of available statistical data and information obtained from trade association and other sources. ... Against the background of this industry-wide inquiry, the affairs of the debtor will be studied. Its position in the industry, the financial and business problems confronting it and the various factors which may be expected to exert a controlling influence on future earnings will all be subjected to analysis and appraisal." ${ }^{73}$ The financial problem of valuation, essential for meeting the legal standard of fairness to all parties in reorganizations, required particularly extensive inquiries. For example, the SEC's report in a case involving a paper company included "over 100 pages of statistical appendices" in order to provide "an analysis of past earnings and of foreseeable changes in conditions and to the estimation of future earnings therefrom." ${ }^{74}$ By conducting such studies, the commission offered "recommendations based on closer study than a district judge could ordinarily 
give to such matters," and in general, federal judges were "grateful for such assistance." The SEC's contribution to Chapter X proceedings, Frank concluded, had transformed corporate reorganizations from "a battle of wits, strategy and endurance" based on litigation into an administrative "study and solution of a problem in financial rehabilitation with conscious attention to the business principles and the public interests involved." 75 Attention to living law thus exposed not a record of heavyhanded government absolutism, but a social reality in which administrative expertise trumped litigation as a means for expediting bankruptcy reorganizations, ensuring fairness to all parties involved, and promoting the public interest.

In his analyses of expertise and administrative flexibility, Frank offered lively variations on themes raised by Landis and Douglas. His most distinctive intellectual contribution to the defense of the administrative state lay in a legal realist analysis that deconstructed the judicial process and thereby eroded the divide between courts and administrative agencies. In his pre-New Deal years, Frank had dedicated much of his writing about jurisprudence to demystifying the work of courts, exposing their real-life operations, and undermining formalist claims about objectivity and logic as the essence of judicial decisionmaking. ${ }^{76}$ At the SEC, in response to the ABA's warnings about the dire consequences of expanded administrative power, he contended that legal and administrative processes did not differ fundamentally in their discretionary authority. In an address puckishly titled "The SEC and the Rubber Hose," Frank discussed at length the well-documented use of brutal and coercive methods in the investigation of criminal cases (as revealed, in particular, by the 1931 Wickersham Commission), prosecutors' acquiescence to the third degree, and the "amazingly unlimited discretion of states attorneys." All criticisms of administrative absolutism, Frank argued, were equally applicable to the court system; furthermore, the SEC's discretionary power paled next to that of prosecutors, and critics such as the ABA had never demonstrated substantial abuses of power by the administrative state. Yet, federal agencies continually confronted dire warnings about their despotic potential, while judicial authority remained largely unquestioned. Given the essential human element in both the judicial and administrative process, Frank insisted, no amount of rule-making could prevent misuses of authority. What mattered were the people in positions of power and "the will of the community" in enforcing standards of conduct. 77

Like Landis, Frank felt compelled to continue defending the New Deal state after he left the SEC, and in If Men Were Angels (1942), he 
synthesized and elaborated upon his earlier ideas about the administrative state. In response to allegations that inaccessibility characterized the New Deal bureaucracy, he pointed to the relative transparency of new agencies, such as the SEC, that voluntarily subjected their actions to public scrutiny, unlike older bureaucracies such as the War Department, Veterans' Administration, and Post Office, which did not generally open their administrative proceedings to the public eye. ${ }^{78}$ More broadly, Frank provided a rationale for the New Deal state by concentrating on the limits of formalism in order to emphasize the similarities between the legal system and administrative agencies. Once one abandoned the enshrinement of law as built on universal, external truths and recognized the degree of subjectivity and personal inclination inherent in the legal process, the comparable range of discretion in the administrative state no longer posed a threat. Here Frank again attacked what he saw as Pound's false distinction between the supposed orderliness of the legal process as opposed to the dangerous free rein of administrative agencies. ${ }^{79}$ In addition to the human elements of judicial decisionmaking, the inherently uncertain nature of facts and the need for subjective judgment in fact determination eroded the notion that law was a rational, rule-based process and courts operated without discretionary power. The ineluctable problem, Frank argued, was that, ultimately, both the courts and the government were only as good as the personnel who staffed them. ${ }^{80}$ Both the courts and government agencies exemplified the problem of personalized, and therefore potentially arbitrary, power. But the personalization of power did not lead to arbitrariness as long as administrative and legal processes maintained transparency, and fact-finders recognized the subjective nature of facts. Not surprisingly, Frank pointed to the SEC as an administrative agency that operated in such a manner. ${ }^{81}$ Fears of administrative government, he indicated, would dissipate with the abandonment of formalist veneration of the courts and a realistic examination of administrative discretion and its policy results.

The efforts of Landis, Douglas, and Frank to construct a legal pragmatist rationale for the New Deal state illustrate how American statebuilding in the twentieth century required not simply new laws and institutions, but also novel cultural and intellectual outlooks that could legitimize the vision of expert-directed policymaking within an expanded administrative state. The same currents that produced such a profound sense of instability and unrest in the late nineteenth and early twentieth centuries-the rise of industrial capitalism, the sense of rapid scientific and technological advancement, and the unsettling feeling of a radical disjuncture between past and present-also provided the intellectual 
resources for fashioning responses to the disorder of modernity. Progressives adopted their distinctive vision of managerial expertise as a way to contain the chaotic reverberations of a newly complex, highly stratified society and render the industrial political economy more stable and humane.

Legal pragmatism emerged from this roiling cauldron of economic upheaval, class conflict, and reform politics as a means of adapting law to the realities of industrial society. Opponents of formalism did not abandon the old ideal of law as a science, but they challenged the prevailing orthodoxy surrounding science itself. Their pragmatism emphasized the uncertain, contingent nature of knowledge, and they sought to replace unitary notions of objective and eternal truth with an understanding of law as a process of inquiry into the constantly changing realities of social and economic life. Law and public policy, from the legal pragmatists' vantage point, had to be comprehended as an arena for dynamic and flexible experimentation in using governmental power to meet human needs.

No mere academic trend, legal pragmatism became under the New Deal both a rationale and a living reality in the conduct of public affairs. As we have seen, the Securities and Exchange Commission embodied the tenets of pragmatic jurisprudence in a variety of ways. It showcased the work of experts in the regulatory process, and it offered a forum for the application of empirical social science to public policy. For Landis, Douglas, and Frank, the new jurisprudence of the 1920s and 1930s ultimately provided crucial intellectual ammunition for defending the prerogatives of the New Deal state and consolidating the place of administrative government in American political life. In a twenty-firstcentury political culture defined by a constant refrain against "big government," legal pragmatism's defense of the New Deal provides an important resource for revitalizing contemporary discussions about the state and its capacities. To ask in the abstract whether a strong administrative state is a good or bad thing seems a useless and vacuous enterprise. As recent studies have indicated, much depends on the individual agency, its political and cultural setting, and its definition of the public interest. On the one hand, the arbitrary and racist policies of the Immigration Bureau at the turn of the century, the heavy-handed moralism of the Post Office during the era of the Comstock Act, and the tortuous workings of the loyalty-security system in the early years of the cold war speak to the repressive potential of administrative power. On the other, the early twentieth-century efforts of the Department of Agriculture's Bureau of Chemistry on behalf of public health and safety, the success of the SEC in rendering the securities market more orderly and humane during the 
1930s, and the potential of the Environmental Protection Agency to help head off global environmental catastrophe should it ever encounter a more receptive political climate all indicate the promise and possibilities of administrative government. ${ }^{82}$ In its depression-era response to the exigencies of industrial capitalism, legal pragmatism proposed an openended future without any of the comforting nostrums of the unrestrained free market at one end of the political spectrum, or the virtues of state control at the other. Instead, it offered uncertainty and hope, which in the long run may prove more enduring values for the conduct of human affairs. $^{83}$

University of California, Los Angeles

\section{Acknowledgments}

I wish to thank the many persons who offered responses to oral and written versions of this essay in its multiple incarnations, especially Thomas H. Broman, Amy Crumpton, Daniel R. Ernst, Paul Forman, David Hounshell, Daniel Lee Kleinman, Alexei Kojevnikov, Lynn K. Nyhart, Alice O'Connor, Philip Pauly, Reuel Schiller, and three anonymous reviewers. I am also grateful to my research assistant, Jessica Breiteneicher Helkin, who helped with my early explorations of nineteenth-century legal science. Finally, I wish to acknowledge the generosity of National Science Foundation Grant \#SES-0135333 and the University of California Council on Research, both of which provided critical financial support for my research.

\section{Notes}

1. Morton J. Horwitz's influential account of the legal realist movement, for example, asserts legal realism's impact on the New Deal but limits its discussion to the debate over administrative procedure and executive reorganization in the late 1930s. Horwitz, The Transformation of American Law, 1870-1960: The Crisis of Legal Orthodoxy (New York, 1992), chap. 8. Daniel R. Ernst has taken Horwitz to task for "the peculiarly abstract and bloodless way in which Horwitz connects legal realism to the 'real political struggles' of early twentieth-century America" and his failure to explore in greater depth the actual workings of the new jurisprudence in politics and public policy. Ernst, "The Critical Tradition in the Writing of American Legal History,” Yale Law Journal 102 (January 1993): 1067.

2. Gerald M. Pops, "Administrative Law as Public Policy: The First Fifty Years," Journal of Policy History 2 (1990): 98-100, emphasizes this neglect.

3. William J. Novak, "The Legal Origins of the Modern American State," in Austin Sarat, Bryant Garth, and Robert A. Kagan, eds., Looking Back at Law's Century (Ithaca, 2002), 249-83, quotations on p. 251. 
4. Part of the neglect of the SEC lies in the persistence of the narrative of the First, Second, and Third New Deals, for the commission's history conforms neither to the planning ethos of the First New Deal nor the left-ward turn of the Second New Deal. The most influential study of New Deal political economy in the past decade, Alan Brinkley's The End of Reform: New Deal Liberalism in Recession and War (New York, 1995), also has little room for the SEC in an analytical framework that charts out the transition from an early New Deal dominated by the planning agenda to the dedication to Keynesian economic management that emerged in the late 1930s and early 1940s. Several of Brinkley's critics have cited his failure to acknowledge those elements of the early New Deal (such as the SEC) aimed at the restoration of capitalism. See Michael K. Brown, "The Ambiguity of Reform in the New Deal," Studies in American Political Development 10 (Fall 1996): 407; and David Plotke, "The Endurance of New Deal Liberalism," Studies in American Political Development 10 (Fall 1996): 417. On this issue, Jordan A. Schwarz, The New Dealers: Power Politics in the Age of Roosevelt (New York, 1993), provides an important counterweight to Brinkley's narrative by concentrating on the New Deal as a form of state capitalism. Not coincidentally, Schwarz's account gives due recognition to the significance of the SEC, although the bulk of his work focuses on other agencies. Detailed accounts of the commission's history remain relegated primarily to several important monographs, cited later in this article.

5. I use the term "legal pragmatism" as an inclusive term covering a variety of intellectual movements that challenged formalist conceptions of law with understandings of legal truth derived from philosophical pragmatism. Robert S. Summers has used the weightier term, "pragmatic instrumentalism," in much the same way. Summers, "Pragmatic Instrumentalism in Twentieth-Century American Legal Thought: A Synthesis and Critique of Our Dominant General Theory About Law and Its Use," Cornell Law Review 66 (June 1981): 861-948.

6. On nineteenth-century judicial practices, see, for example, Peter Karsten, Heart versus Head: Judge-Made Law in Nineteenth-Century America (Chapel Hill, 1997); and William J. Novak, The People's Welfare: Law and Regulation in Nineteenth-Century America (Chapel Hill, 1996). With respect to the case method and nineteenth-century legal science, M. H. Hoeflich, "Law and Geometry: Legal Science from Leibniz to Langdell," American Journal of Legal History 30 (1986): 95-121, argues for the continuity between Langdell's case method and earlier law treatises, whereas William LaPiana, Logic and Experience: The Origin of Modern American Legal Education (New York, 1994) emphasizes the Austinian positivism behind Langdell's jurisprudence and the extent to which the case method's opponents viewed Langdell's approach to law as the enemy of legal truth as defined in the treatise tradition. On the question of formalism as a means for upholding the corporate political economy, Morton Horwitz, The Transformation of American Law, 1780-1860 (Cambridge, Mass., 1977), provides the classic statement of this thesis, but the argument has been hotly disputed. On the historiographical debate, see Ernst, "The Critical Tradition in the Writing of American Legal History"; and John Braeman, "Law and American Economic Development," Journal of Policy History 6 (1994): 470-73. The relationship of courts to the administrative state has been addressed in recent works that have increasingly emphasized frequent willingness of courts to tolerate administrative action, or, in the case of lower courts, to experiment with undertaking administrative functions themselves. See, for example, Lucy Salyer, Laws Harsh as Tigers: Chinese Immigrants and the Shaping of Modern Immigration Law (Chapel Hill, 1995); Michael Willrich, City of Courts: Socializing Justice in Progressive Era Chicago (New York, 2003); Reuel Schiller, "'Saint George and the Dragon': Courts and the Development of the Administrative State in Twentieth-Century America," forthcoming in the Journal of Policy History; and G. Edward White, The Constitution and the New Deal (Cambridge, Mass., 2000), chap. 4.

7. The phrase "a science internal to the law" comes from William E. Nelson, The Legalist Reformation: Law, Politics, and Ideology in New York, 1920-1980 (Chapel Hill, 2001), 24. As William J. Novak has observed, "Although historians have spent much time debating the shift from legal instrumentalism to legal formalism, it is clear that the rationality 
of late nineteenth-century private and public law was both more formalist and more instrumental than the customary and historical jurisprudence of the common law tradition. Late nineteenth-century law was simultaneously more committed to the logic and precision of legal form, category, and rule and more attuned to law's effectiveness as a tool for advancing external societal goals like economic efficiency." Novak, The People's Welfare, 247. Novak thus appears to open the door to Horwitz's thesis about the tight linkage between formalism and industrial capitalism, but Novak views the Civil War as more decisive in promoting the ascendance of individual rights over the salus populi (240-44). Horwitz contends that the mantle of science served both the professional interest "in representing law as an objective, neutral, and apolitical system," as well as the desire of "mercantile and entrepreneurial interests . . . to freeze legal doctrine and to conceive of law not as a malleable instrument of their own desires and interests but as a fixed and inexorable system of logically deducible rules." Horwitz, The Transformation of American Law, chap. 8. William E. Nelson, The Roots of American Bureaucracy, 1830-1900 (Cambridge, Mass., 1982), 133-48, documents the emergence of legal formalism and a growing judicial reliance on natural rights theory, but he emphasizes professional objectives, particularly the desire of judges to give their decisions the imprimatur of scientific truth and avoid acknowledging their actions as policymakers. Nelson observes: "Most American judges sought to clothe their decisions in the language of formal 'logical deduction' ... [,] to make legal reasoning seem like mathematics and to convince themselves that, if men differed over a question of law, it meant simply that one side or the other were not doing their sums right, and, if they would take more trouble, agreement inevitable would come" (144). Nelson's latest study suggests that while classical legal thought frequently served the interests of property, in some cases, such as contract law, formalism ill served the corporate political economy. Nelson, The Legalist Reformation, 63, 90-92.

8. On the general history of the "revolt against formalism," see Morton White, Social Thought in America: The Revolt Against Formalism, rev. ed. (Boston, 1957; originally published New York, 1949); and Edward A. Purcell, The Crisis of Democratic Theory: Scientific Naturalism and the Problem of Value (Lexington, Ky., 1973). Although Columbia law professor Karl Llewellyn asserted legal realism's identity as a distinct and coherent intellectual movement, in reality legal realism owed much to the sociological jurisprudence of Roscoe Pound, and it encompassed such a diverse range of scholars and ideas as to escape the possibility of precise definition. For Llewellyn's attempt at a programmatic statement, see Karl N. Llewellyn, "A Realistic Jurisprudence-The Next Step," Columbia Law Review 30 (April 1930): 431-65. Earlier scholarship on legal realism saw it as a major departure from Progressive Era critiques of formalism, but more recent scholarship has rightly emphasized the continuities. For an example of the former, see G. Edward White, "From Sociological Jurisprudence to Realism: Jurisprudence and Social Change in Early Twentieth-Century America," Virginia Law Review 58 (September 1972): 999-1028. For the latter point of view, see Horowitz, The Transformation of American Law, chap. 6. Horwitz provides a superb analysis of how Llewellyn, helped by Pound's growing conservatism and his refusal to acknowledge some of the more intellectually radical implications of his own approach, created the myth of legal realism's distinctiveness. N. E. H. Hull, Roscoe Pound and Karl Llewellyn: Searching for an American Jurisprudence (Chicago, 1997), also emphasizes the common ground between sociological jurisprudence and legal realism, the clash of personalities between Pound, on the one hand, and Llewellyn and Jerome Frank, on the other, notwithstanding.

9. Oliver Wendell Holmes Jr., The Common Law (Boston, 1881), 1.

10. On Holmes and pragmatism, see Louis Menand, The Metaphysical Club: A Story of Ideas in America (New York, 2001), chaps. 1-3.

11. As Holmes argued in the Harvard Law Review in 1899, "The true science of the law does not consist mainly in a theological working out of dogma or a logical development as in mathematics." Rather, it lay in "accurately measured social desires instead of tradition." Oliver Wendell Holmes Jr., "Law in Science and Science in Law," Harvard Law 
Review 12 (1899): 443, reprinted in Sheldon M. Novick, ed., The Collected Works of Justice Holmes, vol. 3 (Chicago, 1995), 412-13. Two years earlier, Holmes told a Boston University audience that "the man of the future" was "the man of statistics and the master of economics," and he called for the statistical and sociological study of crime in order to find out if the criminal justice system's easygoing assumptions about punishment and deterrence actually held true. Oliver Wendell Holmes, "The Path of the Law," address at Boston University, 8 January 1897, in Novick, ed., The Collected Works of Justice Holmes, 3:391-405, quotation on p. 399; the reference to criminology is on p. 400.

12. For a brief summary of Holmes's critique of classical legal thought, see William M. Wiecek, The Lost World of Classical Legal Thought: Law and Ideology in America, 1886-1937 (New York, 1998), 179-82.

13. On Dewey's pragmatism and his political thought, see Robert B. Westbrook, John Dewey and American Democracy (Ithaca, 1991). For a statement by Dewey himself, see John Dewey, The Public and Its Problems (New York, 1927, reprinted Athens, Ohio, 1991). Although the book was published in the 1920s, in part it recapitulated ideas about democratic community and the need for society to provide for individuals' self-realization that had appeared in Dewey's work as early as the 1880s.

14. Olivier Zunz, Why the American Century? (Chicago , 1998), chap. 2, esp. 33-39.

15. David Wigdor, Roscoe Pound: Philosopher of Law (Westport, Conn., 1974), chaps. 3 and 6-8. Pound was no scientific dilettante. His dissertation, published as the Phytogeography of Nebraska, earned him a reputation as one of the founders of the ecology movement in the United States, and he achieved international recognition during his brief botanical career.

16. See Roscoe Pound, "The Scope and Purposes of Sociological Jurisprudence," part I, Harvard Law Review 24 (June 1911): 611; and Pound, "The Scope and Purposes of Sociological Jurisprudence," part II, Harvard Law Review 25 (November 1911): 146. Pound referred specifically to, among other cases, Lochner v. New York (1905), which struck down a New York state law mandating maximum hours for bakers, and Adair v. United States (1908), in which the Supreme Court invalidated a federal law that attempted to protect workers' right to unionize. The high court contended that both laws, and many other attempts at regulating industrial working conditions, violated liberty of contract.

17. Pound, "The Scope and Purposes of Sociological Jurisprudence," part I, 598. In his critique of classical orthodoxy, Pound contended that formalism produced "a jurisprudence of conceptions, in which new situations are to be met always by deduction from old principles, and criticism of premises with reference to the ends to be subserved is neglected. In the pursuit of principles, there is a tendency to forget that law is a practical matter. The desire for formal perfection seizes upon jurists. Justice in concrete cases ceases to be their aim. Instead, they aim at thorough development of the logical content of established principles through rigid deduction, seeking thereby a certainty which shall permit judicial decision to be predicted in detail with absolute assurance" (596).

18. Roscoe Pound, "The Scope and Purpose of Sociological Jurisprudence," part III, Harvard Law Review 25 (April 1912): 489-516, quotations on p. 513.

19. Ibid., 516.

20. The ranks of the New Deal's legal pragmatists included Thurman Arnold, Felix Cohen, William O. Douglas, Jerome Frank, Walton Hamilton, James Landis, Herman Oliphant, and Wesley Sturges. Robert Jerome Glennon, The Iconoclast as Reformer: Jerome Frank's Impact on American Law (Ithaca, 1985), 84. Felix Frankfurter declined an administrative position, but he served the New Deal closely as an informal adviser, and many of his students became New Dealers, including Landis, Thomas G. Corcoran, and David E. Lilienthal.

21. For background on state "blue sky" laws, the political pressures leading to federal securities legislation, and the legislative history of the 1933 and 1934 acts, see Joel Seligman, The Transformation of Wall Street: A History of the Securities and Exchange Commission and Modern Corporate Finance, rev. ed. (Boston, 1984), chaps. 1-3; Michael E. 
Parrish, Securities Regulation and the New Deal (New Haven, 1970), chaps. 1-3 and 5; and Thomas K. McCraw, Prophets of Regulation (Cambridge, Mass., 1984), 160-81.

22. Although the appointment of Kennedy initially dismayed most New Dealers, he proved a highly capable administrator, who quickly established smooth and effective operations at the SEC. Seligman, The Transformation of Wall Street, chap. 4.

23. Laura Kalman has quipped that legislation was "a subject Langdell would have banned from the curriculum." Kalman, Legal Realism at Yale, 1927-1960 (Chapel Hill, 1986), 52. See also James M. Landis, "The Implications of Modern Legislation to Law Teaching," address to the Thirty-Second Annual Meeting of the Association of American Law Schools, 29 December 1934, copy in Speeches By SEC Officials, 1934-1961, vol. 9, Louis Loss Library, SEC, Washington, D.C.

24. Landis once told Ganson Purcell that one had to avoid letting legislation in the classroom "degenerate into a course in statutory interpretation," in which one taught nothing more than "hollow and sham rules of statutory construction." James M. Landis to Ganson Purcell, 30 November 1931, Box 7, Folder "General Correspondence, 1925-33, Purcell, Ganson," James M. Landis papers, Manuscripts Division, Library of Congress, Washington, D.C. He avoided the pitfalls of formalism by taking his students through legislative procedure and the work of legislative committees before focusing on specific contemporary problems and requiring his students to engage in legislative draftsmanship. Donald A. Ritchie, James M. Landis: Dean of the Regulators (Cambridge, Mass., 1980), 36.

25. James M. Landis to Sidney P. Simpson, 27 May 1936, RG 266, Records of the SEC, Chairman's Files [Landis], Box 1, Folder [Chronological-May 1936], National Archives, College Park, Md.

26. See, for example, Brian Balogh, "Reorganizing the Organizational Synthesis: Federal-Professional Relations in Modern America," Studies in American Political Development 5 (Spring 1991): 119-72; and John M. Jordan, Machine-Age Ideology: Social Engineering and American Liberalism, 1911-1939 (Chapel Hill, 1994).

27. In the case of accounting, for example, the SEC played a major part in building accountants' professional status and increased autonomy by working with the American Institute of Accountants to strengthen standards and bring greater uniformity and rigor to accounting procedures. At the same time, despite its broad statutory powers to establish uniform accounting procedures, the agency deferred to a considerable extent to the professional community's judgment about the range of acceptable practices. McCraw, Prophets of Regulation, 189-92. Historians have rightly faulted the SEC for delegating too much of its authority over accounting standards to the accounting profession. See Parrish, Securities Regulation and the New Deal, 200-208; and Seligman, The Transformation of Wall Street, 116-17 and 197-201. As Landis frequently observed, however, accounting is not an exact science, and therefore the SEC had to accept a variety of professionally developed practices, rather than imposing strict and rigid accounting requirements. See, for example, James M. Landis to J. N. B. Hoxsey, 27 November 1936, RG 266, Records of the SEC, Chairman's Files [Landis], Box 2, Folder "Chronological-November, 1936"; and James M. Landis to Donald Myrick, 3 May 1937, RG 266, Records of the SEC, Chairman's Files [Landis], Box 2, Folder [Chronological-May 1937]. But the lack of more stringent regulatory measures had dire consequences. Decades later, the Enron debacle and other corporate scandals revealed the extent to which accountants remained controlled by the pressure of corporate clients and continued to struggle to establish their professional autonomy. See "Bigger than Enron," Frontline, aired 20 June 2002, transcript available online through www.pbs.org/wgbh/pages/frontline (November 2004).

28. James M. Landis to Editor, Springfield Union (Springfield, Mass.), 9 April 1936, RG 266, Records of the SEC, Chairman's Files [Landis], Box 1, Folder "ChronologicalApril 1936." The quotations actually came from one of Landis's speeches, excerpts of which he included in his letter. Although it might be too much to derive Landis's thinking from John Dewey, it is worth noting that he read Dewey's work and there are suggestive 
parallels between his conception of regulation and Dewey's emphasis on upholding the public.

29. Mary O. Furner and Barry Supple, "Ideas, Institutions, and State in the United States and Britain: An Introduction," in The State and Economic Knowledge: The American and British Experiences, ed. Mary O. Furner and Barry Supple (New York, 1990), 5.

30. Under Herbert Hoover's leadership, the Department of Commerce played a major role in taking the Progressive drive for social intelligence from immigrant communities to the marketplace. William J. Barber, Designs Within Disorder: Franklin D. Roosevelt, the Economists, and the Shaping of American Economic Policy, 1933-1945 (New York, 1996), 117.

31. See William O. Douglas, untitled address, undated [probably late 1928 or early 1929], Box 681, Folder "Speech re. Bankruptcy Laws," William O. Douglas papers, Manuscripts Division, Library of Congress, Washington, D.C.; and Douglas, "A Functional Approach to the Law of Business Associations," Illinois Law Review 23 (March 1929): 673-82.

32. On the shortcomings of legal realism's scientific aspirations, see S. N. VerdunJones, "Cook, Oliphant, and Yntema: The Scientific Wing of Legal Realism," Dalhousie Law Journal 5 (January 1979): 3-44, esp. 17 and 43. Between late 1929 and the summer of 1931, Abraham Flexner and Douglas exchanged a series of letters, in which Flexner roundly criticized Douglas's early bankruptcy research. See Box 5, Folder "General Correspondence, Flexner, Abraham 1929-31," William O. Douglas papers, Manuscripts Division, Washington, D.C. Flexner, then retired, had spent many years as a Rockefeller Foundation official. The foundation was a major patron of the social sciences, including Yale's Institute for Human Relations, and Douglas therefore could not ignore Flexner's reproaches. For a detailed account of Douglas as social scientist, see John Henry Schlegel, American Legal Realism and Empirical Social Science (Chapel Hill, 1995), chap. 2.

33. William O. Douglas, "Some Functional Aspects of Bankruptcy," Yale Law Journal 41 (January 1932): 329-64; quotation on p. 331. Douglas's machine metaphor typified the ideal of social engineering that dominated social science in the early decades of the twentieth century. See Jordan, Machine-Age Ideology.

34. William O. Douglas and J. Howard Marshall, "A Factual Study of Bankruptcy Administration and Some Suggestions," Columbia Law Review 32 (January 1932): 25-59, quotation on p. 31.

35. For the article that caught Landis's attention, see William O. Douglas, "Protective Committees in Railroad Reorganizations," Harvard Law Review 47 (February 1934): 565-89.

36. I have elaborated upon the Protective Committee Study and its larger meaning with respect to empirical knowledge in policymaking elsewhere, in a currently unpublished manuscript.

37. Securities and Exchange Commission, Fourth Annual Report of the Securities and Exchange Commission (Washington, DC: U.S. Government Printing Office, 1938), 74-76; Securities and Exchange Commission, Sixth Annual Report of the Securities and Exchange Commission (Washington, D.C, 1941), 131; Seligman, The Transformation of Wall Street, 189-97; and David A. Skeel, Jr., Debt's Dominion: A History of Bankruptcy Law in America (Princeton, 2001), 119-27.

38. Jerome Frank, Law and the Modern Mind (New York, 1949, sixth printing; originally published by Bretano's, Inc., 1930), 98. Italics in the original. I have discussed Frank's jurisprudence and its relationship to philosophy of science at greater length in an unpublished conference paper: "Technocratic Politics and the New Deal: Jerome Frank, William Leiserson, and Public Policy in the 1930s," Annual Meeting of the Society for the History of Technology, October 2001.

39. On Frank's corporate legal career and his difficult tenure at the AAA, see Kenneth S. Davis, FDR: The New Deal Years, 1933-1937 (New York: 1986), 275-81, 286-88, 299-302, and 475-79.

40. Jerome Frank, "Experimental Jurisprudence and the "New Deal,"” Address before the Association of American Law Schools, Chicago, 30 December 1933, copy in 
Speeches by SEC Officials, 1934-1961, vol. 5. Also reprinted in Congressional Record, 73 ${ }^{\text {rd }}$ Cong., $2^{\text {nd }}$ sess., pt. 11 (18 June 1934): 12412; and as "Realism in Jurisprudence," American Law School Review 7 (1934): 1063-69.

41. On legal realism and Frank's policy innovations at the AAA, see Glennon, The Iconoclast as Reformer, chap. 3, esp. 89-93.

42. Jerome N. Frank to R. P. Mullins, 20 July 1939, Box 27, Folder "Chronological July 1939"; Jerome N. Frank, "DRAFT-July 25, 1939," Box 26, Folder "Brokerage BanksMisc."; Jerome N. Frank to Carle Conway, 10 August 1939, Box 26, Folder "Brokerage Banks-Correspondence Re. Examining Board"; "Concerning expressed willingness of Chairman Frank and SEC to accept substitutes for brokerage bank plan," 26 August 1939, Box 26, Folder "Brokerage Banks-Correspondence Re. Examining Board"; and Jerome N. Frank to Norman Stabler, 29 August 1939, Box 26, Folder "Brokerage BanksCorrespondence Re. Examining Board," all in RG 266, Records of the SEC, Chairman's Files [Frank]; see also Jerome N. Frank, Address before the Association of Customers' Brokers, 23 June 1939, copy in Speeches by SEC Officials, 1934-1961, vol. 5. Ultimately, the SEC accepted self-regulation by Wall Street, when the NYSE adopted a requirement that brokers segregate investors' cash from the rest of their funds, in addition to mandating other rules to govern brokers' banking functions.

43. Jerome N. Frank to Arthur Garfield Hays, 1 March 1940, RG 266, Records of the SEC, Chairman's Files [Frank], Box 27, Folder “Chronological File March 1940.” On another occasion, he defended Chapter X of the Chandler Act in similarly pragmatic terms, arguing that "no inflexible pattern has determined the manner in which this assistance [by the SEC to the courts] may be rendered; rather, the particular variety of procedure in each instance meets the pragmatic test of effective accomplishment of the end which is sought." Frank later added that the commission sought not "moral condemnation" of practices "which the Commission found to have been injurious to investors" but "to assay the social consequences of those practices." Jerome Frank, Address before the American Bar Association, 25 July 1938, copy in Speeches by SEC Officials, 1935-1961, vol. 5.

44. Stephen Skowronek, Building a New American State: The Expansion of National Administrative Capacities, 1877-1920 (Cambridge, 1982). On lower courts' sanction for administrative government during a period in which most historians have emphasized the court system's resistance to expanded administrative power, see, for example, Michael Willrich, "The Case for Courts: Law and Political Developments in the Progressive Era," in Meg Jacobs, William J. Novak, and Julian E. Zelizer, eds., The Democratic Experiment: New Directions in American Political History (Princeton, 2003).

45. Jones v. Securities and Exchange Commission, 298 U.S. 24 (1936).

46. "Report of the Special Committee on Administrative Law," Annual Report of the American Bar Association (Chicago: American Bar Association, 1938), 331-68. On Pound's distaste for legal realism and his attacks on administrative government, see Wigdor, Roscoe Pound, chap. 11; Hull, Roscoe Pound and Karl Llewellyn, chs. 5 and 6; and Horwitz, The Transformation of American Law, 1870-1960, chap. 8. Willrich, "The Case for Courts," highlights Pound's early dedication to court reform over the expansion of administrative government and indicates the underlying consistency between his brand of sociological jurisprudence and his harsh stance against legal realism and its political consequences in the 1930s.

47. Horwitz, The Transformation of American Law, 1870-1960, 230-33. In his ABA report, Pound attacked legal realism as "Marxian" and compared the New Dealers' aspirations for administrative expertise to both fascist and Soviet rule, as well as autocracy more generally. See "Report of the Special Committee on Administrative Law," 340, 343, 345, 360. The most complete account of the political debate over administrative procedure in the late 1930s and 1940s is George B. Shepherd, "Fierce Compromise: The Administrative Procedure Act Emerges From New Deal Politics," Northwestern University Law Review 90 (1996): 1557-683; pp. 1562, 1591, 1602, and 1604-12 document the targeting of the SEC and NLRB. 
48. Chester Lane, "Administrative Law Bill," 22 July 1939, RG 266, Records of the SEC, Documents Concerning Legislation Administered by the SEC, Subject Files, Box 11, [Folder 2]. Shepherd, "Fierce Compromise," 1631 labels the Walter-Logan bill "a deadly struggle for the New Deal's life"; Horwitz, The Transformation of American Law, 1870-1960, 231 observes, "The battle over administrative procedure was nothing less than a struggle over the legitimating premises of the New Deal"; and Barber, Designs within Disorder, 102 notes that at the outset of Roosevelt's second term, before the 1937-38 "Roosevelt recession," government reorganization loomed larger than economic policy on the New Deal agenda.

49. As Dorothy Ross has noted, "There was no more characteristic refrain of the Progressive Era than that economic changes had created a world unknown to the founders and that new industrial conditions required new practices." Ross, The Origins of American Social Science (Cambridge, 1991), 151.

50. James M. Landis, "The Implications of Modern Legislation to Law Teaching."

51. James M. Landis, Address at the $49^{\text {th }}$ Annual Banquet of the Swarthmore Club of Philadelphia, 27 February 1937, copy in Speeches by SEC Officials, 1934-1961, vol. 9.

52. James M. Landis, Address before the Third Annual Eastern Law Students Conference, Catholic University of America, Washington, DC, 20 March 1937, copy in Speeches by SEC Officials, 1934-1961, vol. 9.

53. James M. Landis, "Significance of Administrative Commissions in the Growth of the Law," Address before the Indiana State Bar Association, 9 July 1937, published in Indiana Law Journal 12 (1937): 471-81. The quotations are found on pp. 473-74, and Landis's observations about specialized knowledge are on p. 476. The address was also reprinted in Vital Speeches 3 (1 August 1937): 631-34.

54. Landis, "Significance of Administrative Commissions in the Growth of the Law," 477.

55. Ibid., 479.

56. James M. Landis, The Administrative Process (New Haven, 1938), 7. In his writings and speeches, Landis also continued to stress the contrast between dynamic and static conceptions of law, the need for a pragmatic (in the Deweyan sense) approach to government, and the necessity of expertise and scientific methods in modern government. See, for example, Landis, "Administrative Agencies in Government," Dun's Review (November 1937): 5-8, copy in Box 168, Landis papers; Landis, "Liberty as an Evolutionary Idea," address broadcast on WABC, 27 April 1938, reprinted in Vital Speeches 4 (1 June 1938): 488-89; Landis, "The Role of Law in Regulation," address delivered at Stanford University, published in The State Bar Journal (California) 13 (June-July 1938): 1-7; Landis, "The Place of Administrative Law," address delivered before the Hartford County Bar Association, 17 January 1939, published in Connecticut Bar Journal 13 (April 1939): 71-81; Landis, "Law and the New Liberties," address delivered at the University of Vermont, 7 February 1939, published in Missouri Law Review 4 (April 1939): 105-13; and Landis, "The New Responsibilities of the Professions (Law, Engineering, Banking) in their Relationships with Business Management," address delivered before the Bureau of Personnel Administration, 6 April 1939, copy in Box 164, Landis papers.

57. Landis, The Administrative Process, 55.

58. Ibid., 83.

59. Ibid., 98-100. As SEC chairman, Landis occasionally referred to the restraints that kept administrative power within its proper boundaries. See, for example, Landis, Address at the $49^{\text {th }}$ Annual Banquet of the Swarthmore Club of Philadelphia, 27 February 1937. By and large, however, he concentrated upon outlining the novel features of administrative agencies and their advantages, rather than focusing on appropriate constraints.

60. The quotation is from excerpts of an address by William O. Douglas delivered at the University of Chicago, 27 October 1936, reprinted in James Allen, ed., Democracy and Finance: The Addresses and Public Statements of William O. Douglas as Member and Chairman of the Securities and Exchange Commission (New Haven, 1940), 1. 
61. William O. Douglas, speech before the John Carroll Club of Georgetown Law School, 20 April 1938, Box 684, Douglas papers.

62. William O. Douglas, address sponsored by the Graduate School of Public Affairs of American University and the Graduate School of the Department of Agriculture, 17 April 1937.

63. William O. Douglas, address before the Eighth Annual Forum on Current Problems, sponsored by the New York Herald Tribune, 26 October 1938, copy in Box 686, Douglas papers. For other examples of Douglas's thoughts on administrative flexibility, see, for example, William O. Douglas, address before the Yale Club of Washington, DC, April 1936, reprinted in Allen, ed., Democracy and Finance, 248-55; Douglas, address sponsored by the Graduate School of Public Affairs of American University and the Graduate School of the Department of Agriculture, 17 April 1937, copy in Box 683, Douglas papers; Douglas, address before the Yale Club of Washington, 27 April 1938, copy in Box 684, Douglas papers; and Douglas, address before the Juristic Society of Philadelphia [notes], 21 March 1940, Box 688, Douglas papers.

64. On the contrasts between Landis's and Douglas's terms as SEC chairman, see Seligman, The Transformation of Wall Street, chs. 5 and 6; see also Bruce Allen Murphy, Wild Bill: The Legend and Life of William O. Douglas (New York, 2003), chs. 14-15 on Douglas's chairmanship of the commission.

65. Douglas, address sponsored by the Graduate School of Public Affairs of American University and the Graduate School of the Department of Agriculture, 17 April 1937. A few days later, Douglas again emphasized the "formulation of policies" that resulted from the SEC's handling of "statistics, banking practices, finance, accounting principles and practices, problems of securities distribution, problems of securities exchanges, problems of marketing, of prices, of labor, of production, etc." Douglas, Address delivered to the Columbia Law Review, 23 April 1937. On the importance of the commission's technical work to its policymaking functions, see also William O. Douglas, Address before the National Association of Accredited Publicity Directors, 21 November 1938, Box 686, Douglas papers.

66. See Frank, Law and the Modern Mind, part II, chap. 1.

67. Jerome Frank, "Administrative Flexibility or Industrial Paralysis?" Address before the Georgetown Law Alumni Club, 9 November 1938, copy in Speeches by SEC Officials, 1934-1961, vol. 5.

68. Jerome Frank, "Advance Administrative Decisions," Address before the Association of the Bar of the City of New York, 5 May 1939, copy in Speeches by SEC Officials, 1934-1961, vol. 5.

69. Jerome N. Frank, "Fairness and Feasibility," Address before the Association of the Bar of the City of New York, 27 March 1940, Box 168, Folder 623, Jerome Frank papers, Manuscripts and Archives Sterling Memorial Library, Yale University, New Haven, CT.

70. Jerome Frank, "Some Realistic Reflections on Some Aspects of Corporate Reorganization," Virginia Law Review 19 (April 1933): 541-70.

71. Jerome N. Frank, "The SEC and the Rubber Hose," Address before the Chicago Bar Association, 8 April 1939, copy in Speeches by SEC Officials, 1934-1961, vol. 5. Frank later coined the term "epithetical jurisprudence" to describe attacks on the administrative state based on theoretical arguments rather than empirical evidence.

72. Jerome Frank, "Epithetical Jurisprudence and the Work of the Securities and Exchange Commission in the Administration of Chapter X of the Bankruptcy Act," New York University Law Quarterly 18 (1941): 317-51, quotations on pp. 321-22 and 330, respectively.

73. Ibid., 335 and 336. Frank also cited specific examples from a wide range of Chapter X reorganization cases that had come before the SEC.

74. Ibid., 343.

75. Ibid., 351. 
76. In addition to Law and the Modern Mind, see the following by Jerome Frank: "What Courts Do in Fact," part I, Illinois Law Review 26 (1932): 645-66; "What Courts Do in Fact," part II, Illinois Law Review 26 (1932): 761-84; "Mr. Justice Holmes and NonEuclidean Legal Thinking," Cornell Law Quarterly 17 (1932): 568-603; "Why Not a Clinical Lawyer-School?" University of Pennsylvania Law Review 81 (June 1933): 907-23; and "Experimental Jurisprudence and the 'New Deal."

77. Jerome N. Frank, "The SEC and the Rubber Hose."

78. Jerome Frank, If Men Were Angels: Some Aspects of Government in a Democracy (New York, 1942), 39-40.

79. Ibid., 47 addresses the charge of "administrative absolutism" and Frank's criticisms of "epithetical jurisprudence."

80. Ibid., 92.

81. Ibid., 122. As Frank noted in his 1941 article on Chapter X bankruptcy, all fact judgments remained fundamentally interpretative and open to question. The SEC wanted "only to have it recognized that our conclusions are not mere casual conjectures but are based on intensive factual study, and to have those conclusions carry only such conviction as our study and our reasoning inspire." Frank, "Epithetical Jurisprudence and the Work of the Securities and Exchange Commission," 349.

82. On the Immigration Bureau, see Salyer, Laws Harsh as Tigers. Daniel P. Carpenter, The Forging of Bureaucratic Autonomy: Reputations, Networks, and Policy Innovation in Executive Agencies, 1862-1928 (Princeton, 2001) discusses the Post Office and the Bureau of Chemistry, among other agencies. Unfortunately, no scholar has yet undertaken a statebuilding analysis of the loyalty-security system of the cold war era, although my own work, as well as many other studies, have addressed its abuses. Jessica Wang, American Science in an Age of Anxiety: Scientists, Anticommunism, and the Cold War (Chapel Hill, 1999).

83. On the virtues of hope over certainty, see Richard Rorty, "Truth without Correspondence to Reality" (1994), reprinted in Rorty, Philosophy and Social Hope (New York, 1999), 23-46. 